レーザーオリジナル

\author{
半導体レーザーを光源とする擬似ランダム \\ 変調 CWライダーの試作と動作特性

（1985年 3 月 7 日 受理）

\title{
Construction of a Pseudo-Random-Modulation cw Lidar Using a Laser Diode
}

\begin{abstract}
Nobuo TAKEUCHI, Hiroshi BABA**, Katsumi SAKURAI**, Toshiyuki UENO***, Ken IDOTA***, Toshihiro ARAI****, Masato TSUNEMI***** and Naoki ISHIKAWA*****
\end{abstract}

(Received March 7, 1985)

\begin{abstract}
Random-modulation cw (RM-CW) lidar has characteristics that make it possible to use a small-power cw laser as the light source. Development of laser diodes (LD) has been very rapid recently. The laser diode is compact in size and can be driven with little energy compared with traditional lasers, so that it is the most promising candidate for use in a portable, compact and practical lidar system. In this paper, a prototype portable RM-CW lidar system with an LD light source is reported. This is the first report of a practical LD system, to the authors' knowledge. Measurements of the spatial aerosol profile up to several hundred meters, as well as cloud ceiling-height up to several kilometers, were detected, at night time with this system and are shown in this paper.
\end{abstract}

\section{1.はじめに}

ライダー (レーザーレーダー $)^{11}$ は大気中の 物質の分布状態や物体までの距離を遠隔的に測
定するための装置で, レーザーの重要な応用分 野の 1 つである。物質からの散乱信号光は微弱 であるので, 通常, 大出力のパルスレーザーが

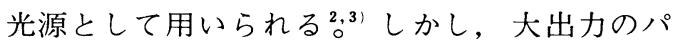

* 国立公害研究所大気環境部 ( $\overline{0} 305$ 茨城県筑波郡谷田部町小野川16-2)

**東京大学教養学部基礎科学科（T153 東京都目黒区駒場 $3-8-1$ )

***千葉大学工学部機械工学科 ( ₹260 千葉市弥生町 1-33)

****筑波大学物理工学系 ( 7305 茨城県新治郡桜村天王台 $1-1-1$ )

****** 明星電気(株) ( T302-01 荻城県北相馬郡守谷町大字守谷甲249-1)

* National Institute for Environmental Studies (16-2, Onogawa, Yatabe, Tsukuba, Ibaraki 305)

** Dept. of Pure and Applied Science,The Univ. of Tokyo (3-8-1, Komaba, Meguroku, Tokyo 153)

*** Dept. of Mechanical Engineering, Chiba Univ. (1-33, Yayoicho, Chiba 260)

**** Inst. of Appl. Phys, The Univ. of Tsukaba (1-1-1, Ten-nodai, Sakuramura, Niiharigun, Ibaraki 305)

***** Meisei Electric Co., Ltd. (249, Moriya, Kitasoumagun, Ibaraki 302-01) 
ルスレーザーを光源とする場合, 装置が大型化 し，ライダーの普及を妨げる要因となっている。 著者らは, CWライダーを光源として, 散乱体の 空間プロファイルを得ることができる擬似ラン ダム変調 $\mathrm{CW}$ ライダー $(\mathrm{RM}-\mathrm{CW}$ イイダー $)$ を提 案し，アルゴンレーザーを光源として装置を構 成し, 大気中のエアロゾル空間プロファイルを 測定した結果を報告した ${ }^{4,5)}$ 。CWライダーとして は, 周波数変調 (FM) CWライダーが提案され ${ }^{6}$, その基礎実験が行われている ${ }^{7 !}$ 。 RM-CWライダ 一は振幅または位相を擬似ランダムコードによ つて変調する。その自己相関が $\delta$ 関数的である ことを利用して, 受光散乱信号光と遅延させた 変調信号との相関をとって, 散乱体の空間信号 を得る手法である。

RM-CWライダーでは同じピークパワーのパル スライダーに比べて大気中へ送出する出力は小出 力で済むので, 光源出力に対する要求は緩やかと なる。したがって最近発展の著しい半導体レー ザー（レーザーダイオード：LD）を光源とする のに最も適した手法である。 LDはcw動作で約 $100 \mathrm{~mW}\left(\right.$ アレイタイプ) ${ }^{8}$ のものが, パルス動 作で数 $\mathrm{kw}\left(\right.$ アレイタイプ ${ }^{9 !}$ のものが, 市販さ れている。ライダーの場合, 昼間の背景光雑音 を抑えるために，レーザー発振光の周波数が安 定でしかもスペクトル幅が狭いことが要求され る。アレイ型であっても, 位相結合（phase locking）によって単一モード発振が実現され ている ${ }^{10)}$ 。 パルス動作でも単一モードで動作す るDSM (Dynamic Single Mode) レーザー ${ }^{11}$ が研究されている（この場合 DFB（Distributed Feed-Back)構造なよ゙, 特殊の構造が 必要である)。したがって単一モード動作を容易 にしかも安定に利用できる点からも CWライダー 方式が適している。パルス動作の L D を光源と するライダーとしては，斜め視程計への応用 ${ }^{12}$

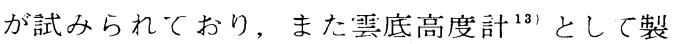
品化されているが, 大気中の散乱体（エアロゾ ル, 排煙等) の空間分布を精度良く, 小型簡便 なシステムで測定した報告はなされていない。

本論文では L D を光源として，エアロゾル空
間分布を本格的に測定した最初の例として， R M- CWライダーの試作とその動作特性を報告す る。本システムは, 1 人で運搬・操作できる小 型で可搬なシステムとして，近距離のエアロゾ ルや排煙・排ガスの空間分布状態や, 大気境界層 構造, 雲底高度, 視程等を測定対象として設計・ 製作された。実際には，15mWの出力 (平均7.5 $\mathrm{mW})$ の $\mathrm{LD}$ を光源として，夜間，数 $\mathrm{km}$ 遠方の雲 や数 $100 \mathrm{~m}$ までのエアロゾルの空間分布の測定を 行うことができた。以下に，L D を光源とする ライダーの特徵, RM-CWライダーの原理と概 要, 試作したライダー装置の仕様, 測定例につ いて述べる。

\section{LDライダーの特徵}

半導体レーザー（LD）は光ファイバーと組み 合わせて, 光通信用の光源に用いられるだけで なく, 光ディスクの読み取りやレーザビームプ リンターの光源として実用化されており，それ らの L D を小型可搬な RM-CWライダー光源と して用いることが可能である。

L D をライダーの光源として使用する際の必 要条件は,

1) レーザー出力が十分あること

2）空間分解能を得るのに十分な変調速度が得 られること

3)大気の透過率が良い (“大気の空”) 領域で 発振すること

4 ）背景光を除去するのに十分なだけ単色で安 定に発振すること

5 ）検出器感度が良好な波長帯で動作すること

6 ）光軸調整等の観点からは可視域が望ましい, などである。

また, L D は他のレーザーと比べて次の特徴 を持つ：

$1^{\circ}$ 小型軽量である。

$2^{n}$ 低電圧, 小電」で駆動できる。

$3^{\circ}$ 出力を容易に電流変調できる。

$4^{\circ}$ 温度や駆動電流によって同調可能である。

$5^{\circ}$ 低価格である。

$6^{\circ}$ 長寿命である。 
特に出力を電流変調できることは，Arレーザー を光源のする場合のような光変調素子を必要と しないので， RM- CWライダーにおける変調方 式を極めて簡単にする。

現在利用できる LDはGaAlAs系の650～950 $\mathrm{nm}, \mathrm{InGaAsP}$ 系の $1.0 \sim 1.6 \mu \mathrm{m}, \mathrm{Pb}$ 化合物系の $4 \sim 32 \mu \mathrm{m}$ である。このうち $\mathrm{Pb}$ 化合物系は動作 時に冷却を必要とする。現状では GaAlAs 系の $\mathrm{LD}$ の方がInGaAsP系よりも大きな $\mathrm{cw}$ 出力を 与える。GaAlAs系では830〜850 nm領域と780 $\mathrm{nm}$ 領域を中心に開発が進められており，前者 は光ディスクに，後者はレーザービームプリン 夕に使用されている。光学的調整, 検出器感度 の点からはさらに短波長の L D が適しているが, 短波長領域の L D は現状では信頼性に欠けてお り，市販されていない。780 $\mathrm{nm}$ の波長域は夜間 にレーザービームを識別可能であり, 大気中の 水蒸気の吸収線も非常にまばらな領域である。 また，高感度な感度曲線が長波長側まで伸びて いる $\mathrm{GaAs}$ 光電面をもつ光電子増倍管 $(\mathrm{PMT}$ ) の長波長側の限界波長でもある。この波長領域 では位相結合型のアレイタイプで $100 \mathrm{~mW} の$ 単 一モ一ド発振も報告 ${ }^{14)}$ されており，目に対す る安全性の観点も含めて, ライダー光源に適し た波長である。

\section{RM-CWライダーの原理と概要}

RM-CW ライダーの原理については文献 5 ) で既に述べてあるので，ここでは概要のみを紹 介する。擬似ランダムコードは時間系列の自己 相関関数が $\delta$ 関数的な性質をもつ信号系列であ る ${ }^{15)}$ 。本実験では周期的な擬似ランダムコード である M系列（最大周期列， maximum length shift register sequence) を使用した。nケの シフトレジスターを使用して $N=2^{\mathrm{n}}-1$ を周期 とする $\mathrm{M}$ 系列を得る。 $\mathrm{M}$ 系列のサンプリング時 間を $\Delta t$ とするとき, $\mathrm{M}$ 系列の 1 周期 $T$ は $T=$ $N \Delta t$ となる。シフトレジスターから得られる $\mathrm{M}$ 系列は“1”, “0”の元から構成される(これ を $a_{i}$ と呼ぶ。 $a_{i}=1$ または $\left.0, i=1 \sim N\right)$ 。 “1”, “0”を“1”, “一 1 ”に対応させた系列
が自己相関関数が $\delta$ 関数的となる $\mathrm{M}$ 系列である (これを $a_{i}{ }^{\prime}$ と呼ぶ)。 $a_{i}$ と $a_{i}{ }^{\prime}$ の相互相関関数 $\phi_{\mathrm{aa}}{ }^{\prime}$ (j) は次式で与えられる：

$$
\phi_{\text {aa' }}(j) \equiv \sum_{i=1}^{N} a_{i} a_{i+j}^{\prime}=\left\{\begin{array}{cl}
(N+1) / 2 & j=0(\bmod , N) \\
0 & j \neq 0(\bmod , N)
\end{array}\right.
$$

大気中にM系列で変調された光出力 $x_{i}=P_{0} a_{i}$ $\left(a_{i}=1\right.$ または 0$)$ を送出するものとする。(本 システムではインコヒーレント検出法を使用す る。コヒーレント検出法を使用するコヒーレン トライダーでは位相をサンプリング時間 $\Delta t$ 毎に $\mathrm{M}$ 系列 $a_{i}^{\prime}$ の “ 1 ”, “- 1 ”に応じて0, $\pi$ に切り換 える。この場合には $x_{i}=P_{0} a_{i}^{\prime}$ となり, $\mathrm{RM}-\mathrm{CW}$ ライダーは文字通り CWライダーとなる。 $\mathrm{S} / \mathrm{N}$ の式はインコヒーレントの場合と異なる。)

単位強さの光入力に対する大気中の散乱体の 空間分布を反映する応答関数を $G_{i}$ とする（ $i$ は 時間を $\Delta t$ 刻みで数えたとき, $i \Delta t$ 時間後の信号 であることを示す）と，RM-CWライダーでは Fig. 1 に示すように, 送信光 $x_{i}$ と応答関数 $G_{i}$ の畳み込み (convolution) によって受光散乱信 号 $y_{i}$ が与えられ,

$$
\dot{y}_{i}=\sum_{j=1}^{N} x_{i-j} G_{j}+b+n_{i}
$$

となる。ここで $n_{i}$ は時間 $i \Delta t$ における検出器の ポアッソン雑音で, 期待值は零である $\left(E\left[n_{i}\right]\right.$ $=0)$ 。bは背景光強度で一定值を与える。応答 関数 $G_{j}$ は,

$$
G_{j}=\eta(c \Delta t / 2) A_{\mathrm{r}} \beta_{j} T_{j}^{2} Y_{j} / R_{j}^{2}
$$

で与えられる。 $\eta$ は光学系の効率, $c$ は光速度 $\left(c \Delta t / 2\right.$ は空間分解能) である。距離 $R_{j}$ は $j c \Delta t$

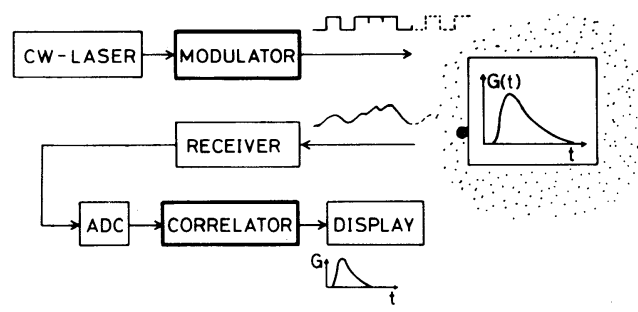

Fig. 1 Schematic diagram of the "Random-modulation" CW (RM-CW) lidar. 
/2で与えられる。 $A_{\mathrm{r}}$ は受光光学系開口面積, $\beta_{j}$ は距離 $R_{j}$ からの微分後方散乱係数, $T_{j}$ は $R_{j}$ までの透過率， $Y_{j}$ は $R_{j}$ におけるレーザービーム が望遠鏡視野に含まれる割合である。

RM-CWライダーでは空間分解能はサンプリ ング時間 $\Delta t$ にって $c \Delta t / 2$ で与えられる。ま た応答関数は $c T / 2(=N c \Delta t / 2)$ の繰返し関数 として与えられる。したがって周期性による測 定誤差を無視できるためには， $R=c T / 2(=N$ $c \Delta t / 2)$ における応答関数の值が許容誤差以下 でなければならない。

受光信号 $y_{i}$ から応答関数 $G_{i}$ を求めるには, 擬 似ランダムコードの自己相関関数が $\delta$ 関数的性 質をもつことを利用して,$y_{i}$ と $a_{i}{ }^{\prime}$ (この場合 $a_{i}$ でなく $a_{i}{ }^{\prime}$ 用いることに注意）との相関

$$
S_{\imath}=\sum_{i=1}^{N} y_{i} a_{i+l}^{\prime}
$$

をとる。(実際にはFig. 1 に示すように $y_{i} を \mathrm{AD}$ 変換器 $(\mathrm{ADC})$ でディジタル化した後で相関を とる。) $S_{l}$ の期待値 (時間平均值) $\bar{S}_{l}$ は式 (1)の 関係を用いて,

$$
\bar{S}_{l}=\left[S_{\imath}\right]=P_{\mathrm{o}} \frac{N+1}{2} G_{l}+b
$$

となる。

検出器出力信号の変動はポアッソン分布に従 うので,

$$
E\left[n_{i}{ }^{2}\right]=(1 / \xi)\left(\sum_{j=1}^{N} x_{i-j} G_{j}+b\right)
$$

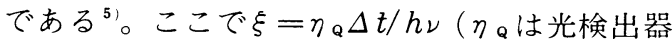
の量子効率, $h$ はプランク定数, $\nu$ はレーザー 周波数）は信号強度（パワー）を光電子数へ変 換する係数である。したがって，相関 $S_{l}$ の分散 は

$$
\begin{aligned}
V\left[S_{l}\right]= & E\left[\left(S_{l}-\overline{S_{l}}\right)^{2}\right] \\
& =(N / \xi)\left(P_{0} \frac{N+1}{2} \bar{G}+b\right)
\end{aligned}
$$

で与えられる。ここで $\bar{G}=(1 / N) \sum_{j=1}^{N} G_{j}$ は応答 関数の平均値である。相関 $S_{l}$ の分散は (6) 式か ら分るようにl(したがって距離 $R$ ) によらず一 定となる。

ディジタル化の誤差による分散は, ADCの入
力の時点で一様分布を仮定すると, ADCのレベ ルの最小刻み $(\mathrm{LSB})$ を $\Delta q$ とするとき, $(\Delta q)^{2}$ /12で表わされる。相関演算を行うときにディ ジタル化の誤差は平均化されるので，その誤差 の分布形は中心極限定理によって正規分布に近 ブく。しかし， $S_{l}$ に入ってくるディジタル化の 誤差による分散はそのまま $N$ 倍される。

ライダーの $\mathrm{S} / \mathrm{N} は S_{l}$ の期待值（信号分） と 標準偏差 $\sigma$ (分散の平方根）の比によって与え られる（本論文では $\mathrm{S} / \mathrm{N} の$ 定義として振幅の比 を用いる）：

$$
\begin{aligned}
& \mathrm{S} / \mathrm{N}=\frac{\bar{S}_{l}}{\sqrt{V\left[S_{l}\right]}} \\
& =\frac{\sqrt{M} \xi P_{0}(N+1) G_{l} / 2}{\sqrt{N} \sqrt{\xi \mu\left(P_{0}(N+1) \bar{G} / 2+b\right)+(\Delta p)^{2} / 12}}(7)
\end{aligned}
$$

ここで $\mathrm{M}$ は測定時間に含まれる $\mathrm{M}$ 系列信号の周 期 $(N \Delta t)$ の繰返し数である。 音指数で, PMTでは $2 \sim 3$ の值をとる ${ }^{16)}$ (7)式 における $\Delta p$ は $\Delta q$ を光電面における等価光電子 数に換算した值で, $\Delta q=\Delta p(e / \Delta t) R_{l} M_{\mathrm{PM} \mathrm{T}}$ $M_{\mathrm{AM}}$ の関係がある $\left(e\right.$ は電子の電荷, $R_{l}$ は $\mathrm{PMT}$ の負荷抵抗值, $M_{\mathrm{PMT}}, M_{\mathrm{AMP}}$ はそれぞれ $\mathrm{PMT}$ および増幅器の増倍率である。

(7)式を用いた計算例として，20 $\mathrm{mW}$ の $\mathrm{cw}$ レー ザー(duty ratio 50\%なので平均パワー $10 \mathrm{~mW}$ ) を光源として, 視程 (レーザー光の透過率が1） 50 となる距離） $5 \mathrm{~km}$ に相当するエアロゾルに対 して, $\mathrm{S} / \mathrm{N}=10$ を得るのに必要な測定時間を Fig. 2 に示した。距離分解能 $(\Delta R=c \Delta t / 2)$ は $9 \mathrm{~m}(\Delta t=60 \mathrm{~ns})$ を仮定している。その他の 装置の仕様は次節 Table I に示す通りである。 昼間時の計算に用いた背景光強度は $8 \times 10^{-2} \mathrm{~W}$ $/ \mathrm{m}^{2} / \mathrm{sr} / \mathrm{nm}$ である。これは晴天時の明るいと きの天空光輝度に相当する。昼間晴天時に $1 \mathrm{~km}$ まで測定するには，100 $\mathrm{mW}$ (平均 $50 \mathrm{~mW}$ ) のLD を用いた場合，100秒の測定時間で $\mathrm{S} / \mathrm{N}=3$ が 得られる。

\section{LD を光源とする RM-CW ライダー}

本装置の製作の目標は，1人で運搬・操作で きる小型ライダーシステムの製作である。Fig. 


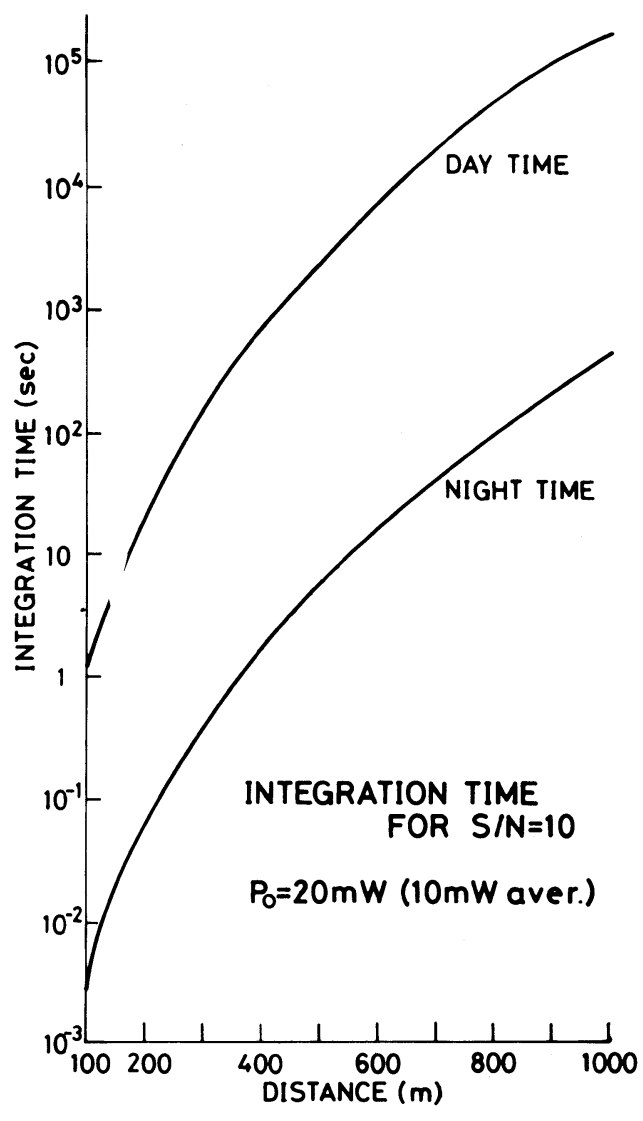

Fig. 2 Estimation of the integration time (measurement time) necesary for measuring aerosol profile with spatial resolution of $9 \mathrm{~m}$ and $\mathrm{S} / \mathrm{N}=10$. Diode laser power is assumed to be $20 \mathrm{~mW}$. Other conditions are the same as in Table I.

2 に示したように大気中のエアロゾルに対して はほぼ $1 \mathrm{~km}$ で測定できる。もつと高濃度の物 質に対してはさらに遠方までの測定が可能であ る。RM-CWライダーでは小出力の cwレーザー を光源として使用できるので，半導体レーザー （LD）を光源として採用したことが本装置の最 大の特徴である。L D を光源とする小型可搬な RM-CWライダーについて, 装置の概要, レー ザー部, 送受光部, 信号処理系, 制御部および 制御プログラムについて以下に述べる。

\section{1 装置の概要}

Table I Specification of a Diode Laser (LD) $\mathrm{RM}-\mathrm{CW}$ Lidar.

\begin{tabular}{|c|c|}
\hline Laser & GaAlAS-LD (Sharp LT-024MD) \\
\hline Wavelength & $778 \mathrm{~nm}\left(15^{\circ} \mathrm{C}\right)$ \\
\hline Power & $15 \mathrm{~mW}(\max 30 \mathrm{~mW})$ \\
\hline Mod. Current & $80 \mathrm{~mA}($ bias $40 \mathrm{~mA}+\bmod .40 \mathrm{~mA})$ \\
\hline \multicolumn{2}{|c|}{ Temp.Tun. Range $0-30^{\circ} \mathrm{C}$} \\
\hline \multicolumn{2}{|c|}{ Wavelen.Tun. Range $7 \mathrm{~nm}$} \\
\hline \multicolumn{2}{|c|}{ Beam Divergence $0.1 \mathrm{mrad}$ (after collim.) } \\
\hline \multicolumn{2}{|c|}{ Psuedo-random Modulation on-off style } \\
\hline \multicolumn{2}{|c|}{ Code $\quad$ Binary $M$-sequence } \\
\hline No. of Elem. (N) & 4095 \\
\hline Sampling Time & $\Delta t=60 \mathrm{~ns}$ \\
\hline Range Resolution & on $\Delta R=9 \mathrm{~m}$ \\
\hline Period & $T=\Delta t \times N$ \\
\hline \multicolumn{2}{|l|}{ Receiving Optics } \\
\hline Telescope & Reflection-type (Cassegrainian) \\
\hline Aperture & $13.5 \mathrm{~cm}$ \\
\hline \multicolumn{2}{|c|}{ Effective focal length $40 \mathrm{~cm}$} \\
\hline \multicolumn{2}{|c|}{ Field of View $\quad 2 \mathrm{mrad}$} \\
\hline \multicolumn{2}{|c|}{ NB-IF filter band width $1.2 \mathrm{~nm}$} \\
\hline \multicolumn{2}{|c|}{ Sep. bet. laser \& Teles. } \\
\hline \multicolumn{2}{|c|}{ Detector PMT } \\
\hline \multicolumn{2}{|c|}{ Quantum Effi. $Q=0.1$} \\
\hline \multicolumn{2}{|c|}{ Dark Current $0.1 \mathrm{nA}$} \\
\hline \multicolumn{2}{|r|}{$\begin{array}{ll}2-3 & \left(M_{\mathrm{D}}^{\mathrm{x}}\right)\end{array}$} \\
\hline Amp. Factor & $2 \times 10^{5} \quad\left(M_{\mathrm{D}}=100 \quad(\right.$ ty.$\left.)\right)$ \\
\hline Amplifier Gain & $70 \mathrm{~dB}$ \\
\hline \multicolumn{2}{|c|}{ Signal Processor } \\
\hline $\begin{array}{l}\text { ADC } \\
\text { accumulation }\end{array}$ & up to $2^{16}$ \\
\hline Correlation & hard system \\
\hline Control/Display & $\begin{array}{l}\text { Personal computer (Sanyo } \\
\text { MBC225) }\end{array}$ \\
\hline
\end{tabular}

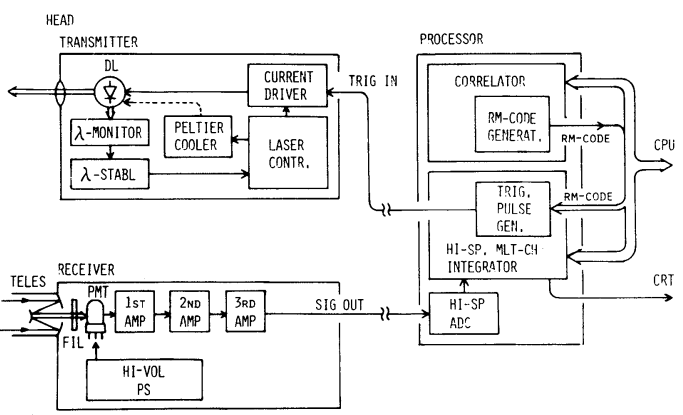

Fig. 3 Block diagram of the diode laser (LD) RM- CW lidar (Head 〔transmitter and receiver] and processor parts). 
LDを光源とする RM-CWライダー装置のブ ロック罒をFig. 3 に，仕様をTable Iに示す。 装置全体は送・受信光部, 信号処理部, 制御用 パーソナル・コンピュータ（パソコン）から成 る（Fig. 3 には前 2 者が示してある）。送・受光 部は同一のフレーム（送受光用へッド）の中に 隣り合わせて格納され，一体化されている。送 受光へッドは, 信号処理部と $5 \mathrm{~m}$ のケーブルで 結ばれ，測量用三脚の上にマウントされ，任意 の方向を向けることが可能である。全システム はパソコンからのコマンドにより自動的に操作 が可能である。以下にL D と他の構成部に分け て各部仕様を説明する。

\section{2 半導体レーザー素子}

光源としての半導体レーザー (LD) に780 nm 領域で市販（国内）では最大のcw出力を与える シャープLT-024MDを使用した。同素子はVS IS (V-channeled substrate inner stripe) 型 の GaAlAs系LDで, cw動作の最大定格は $30 \mathrm{~m}$ $\mathrm{W}$, 発振しきい值電流は45～ $50 \mathrm{~mA}$, ビーム拡が りは接合面に平行な方向は半値全角が $10^{\circ}$, 垂直 方向は $30^{\circ}$ であった。 RM-CWライダー装置で は常時 $40 \mathrm{~mA}$ のバイアス電流を流し, M系列の “1”に対応して，60nsの矩形波状の電流パル ス（振幅40～50 mA）を印加した。レーザー発 光パルス波形は10～90\%值でみると，立上り時 間 $6 \mathrm{~ns}$ ，立下り時間 $7 \mathrm{~ns}$ であるが，立下りは波 高の $5 \%$ 程度の尾をさらに13 ns ばかりひきずる (これは駆動電源回路の影響もあるものと思わ れる)。動作時の代表的出力は $15 \mathrm{~mW}$ (平均出力 $7.5 \mathrm{~mW})($ ニッコーム, サーモフィルム $\mathrm{LP}-31$ Bで測定）であった。

レーザー発振の波長制御は, ペルティエ素子 によって素子温度を制御して行った。素子温度 に対する発振波長の変化の 1 例をFig. 4 に示す。 Fig. 4 における発振波長の平均的変化は, 0.25 $\mathrm{nm} /{ }^{\circ} \mathrm{C}$, 同一モード上での変化は $0.06 \mathrm{~nm} /{ }^{\circ} \mathrm{C}$ で ある。これはGaAlAs系LDの一般的な值 0.26 $\mathrm{nm} /{ }^{\circ} \mathrm{C}, 0.08 \mathrm{~nm} /{ }^{\circ} \mathrm{C}$ とほほ一致する。適当な動 作温度を選択することによって単一モードで安

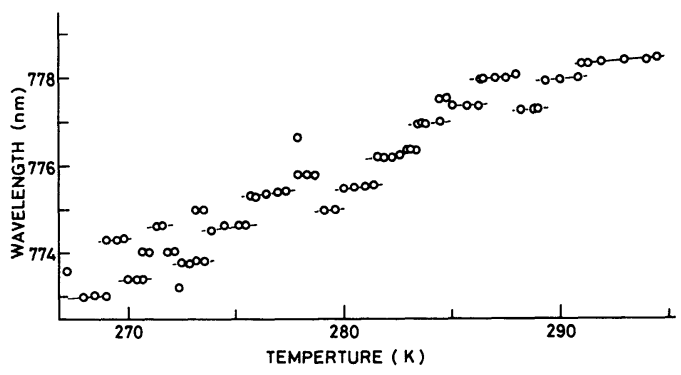

Fig. 4 Lasing frequency shift as a function of LD mount temperature.

定な動作を得ることが可能である。

夜間測定では狭帯域光学フィルターをはずし て測定を行ったが，昼間測定ではＬＤの動作波 長とフィルターの透過中心波長を一致させる必 要がある。昼間時測定において $\mathrm{S} / \mathrm{N}$ 向上させ るためにはレーザー出力を向上させる必要があ る。100 mWのアレイ型素子を用いると出力強度 を 7 倍に向上させることが可能である。

\section{3 送受光部}

送受光部へッドの写真をFig. 5 に示す。ヘッ ドには送光部および受光部が隣りあって配置さ れている（両光軸間距離 $220 \mathrm{~mm}$ )。

送光部はLDおよびLD駆動電源, 波長モ二タ 一およびレーザー波長制御用温度制御装置から 成る。本装置ではL D 動作温度は温度制御用冷 却装置を働かせて Fig. 4 で示される安定な発振 波長を与える值に保たれた。

レーザー発振波長は $f=50 \mathrm{~mm}, F=1.3$ のメ ラレンズによって平行光にコリメートされ, 大

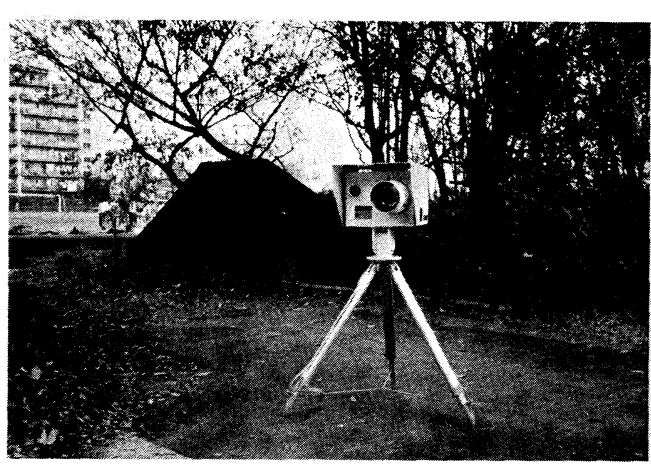

Fig. 5 Photo of the LD RM-CW lidar head. 
気中へ射出される。ビーム拡がりの最小值は 0.1 mrad以下であった。

大気中で後方散乱された信号光は口径 $135 \mathrm{~mm}$, 有効焦点距離 $400 \mathrm{~mm}$ のカセグレン型反射望遠鏡 によって集光される。望遠鏡の視野角は焦点位 置におかれた可変絞り（Melles Griot製，最 小口径 $0.8 \mathrm{~mm}$ ）によって $2 \mathrm{mrad}$ に抑えられる。 集光された信号光はレンズによって平行にされ， 狭帯域光学フィルター（夜間測定では不使用）を 通過した後，レンズで光電子増倍管 $(\mathrm{PMT})$ に 集光される。受光信号光は初段増幅器でインピ ーダンス変換された後， 3 段增幅され，信号 処理系へ送られる。増幅器の全利得は $74 \mathrm{~dB}$ であった。なお，原仕様ではP M T の代りにア バランシェフォトダイオード (APD) を検出器 に使用していた。この場合, A P D の過剩雑音 を小さく抑えると増幅器利得が不足し, 構造物 や排煙の測定を行うことはできたが，稀薄な工 アロゾルの空間分布の測定は, 検出器を P M T に替えて初めて可能となった。

\section{4 信号処理系}

信号処理系は $\mathrm{AD}$ 変換器 $(\mathrm{ADC})$, 多チャンネ ル積算器, 相関演算器から成る。P M Tで受光 された信号光は増幅器で増幅され，信号処理系 へ導かれる。その際に変調周波数を含む高周波 を高域沪波フィルターでカットし，受光系に混 入する変調信号の影響を除去することができる。

信号処理系へ導かれた受光信号は，3ビット ADC (Datel HU3 BMC) へ入力され, ディジ タル化される。 $\mathrm{ADC}$ のンプリング時間は最 小20nsであるが通常60nsで使用した。大力信号 を少いビット数で歪みなくディジタル化するた めに，入力信号レベルのヒストグラムをモニタ 一し，1 LSBに対する信号レベルおよび入力信 号のオフセット值を調整した。Fig. 6 に積算部 ボードに配置された A D C と多チャンネル樍算 器（MC A）のブロック四を示す。相関演算器 (Fig. 7 参照) の中のランダムコード生成器 ( R $\mathrm{CG}$ ）では12ケのシフトレジスターに帰還をか けて exclusive ORをとることによって4095（=

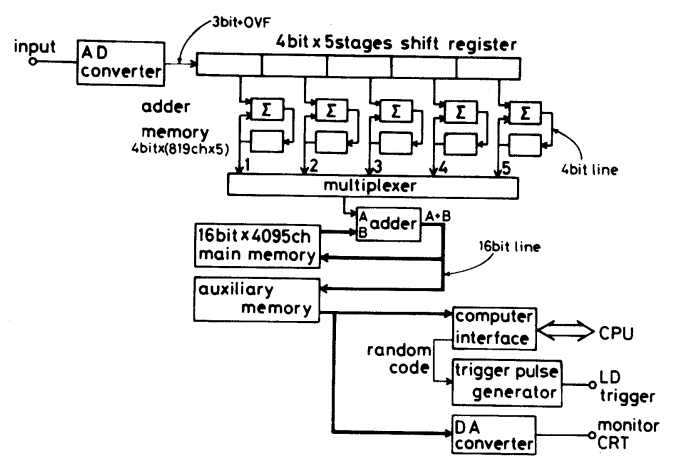

Fig. 6 Block diagram of the accumulation part of the processor unit.

$12^{12}$ - 1 ）を周期とする M系列ランダムコード が生成される。クロック周波数は水晶振動子に よって決定され，16.67 MHz（クロック時間 60 ns）を基本として，その $1 / 2 ， 1 / 5 ， 1 / 10 ， \cdots \cdots$.゙選 択できる。R C Gで生成された高速の変調信号 は一度パソコンの C P Uを経由して積算部ボー ド（Fig. 6）上のトリガーパルス生成器を通し て送光部に送られ，L D 駆動の変調コードとな る。このように本装置では $60 \mathrm{~ns} の$ 高速パルスで 変調された信号光を扱うため, M C A は高速積 算部と（低速度の）主積算部に分けて処理を行 ている。高速積算部は 5 ケのシフトレジスター によって，A D Cでディジタル化された 1 周期 4095ケの信号を819ケずつ 5 ブロックに振りわ ける。これによりメモリーへの積算速度を1/5に スローダウンし，4ビット 819 チャンネル $\times 5$ ブロックの高速メモリーに 5 周期分積算する。 5 周期分積算された 4 ビットの高速積算部デー 夕は16ビットの主積算部へ転送・積算される。

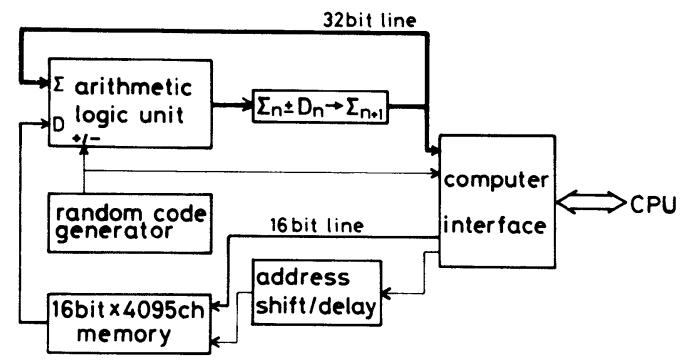

Fig. 7 Block diagram of the correlation part of the processor unit. 
主積算部の内容は補助メモリーヘコピーされ， 積算中, その内容を C R Tに表示したり, パソ コンへ転送する。

もう一つの信号処理系の機能は相関演算であ る。相関演算器部のブロック困を Fig. 7 に示し た。積算データの復調処理は, 変調擬似ランダ ムコードとの相関を遅延時間（擬似ランダムコ 一ドの位相）をずらしながら取って行うが，そ の処理はコード長 $N$ に対して $N^{2}$ 回の加減算が必 要である。本装置では専用ハードウェアによっ て相関演算を行う。その際, 積算データはCPU から転送され, 一度, 相関演算器内のメモリ一 に格納され，CPUからの制御コマンドに従っ て, 加減演算が行われる。 $N=4095$ の周期の相 関演算は約 1 秒で処理される。復調結果はCRT 上に表示される。

\section{5 制御部および制御プログラム}

制御部はパソコンおよびその周辺機器から構 成され，システムの制御，データ処理を行う部 分である。パソコンは主としてサンヨーM B C 225 を用い, 必要な場合にNEC PC9801F 2 を 使用した。

制御項目としては 1) 測定の開始・終了，2） 相関演算の実行および計算結果の表示，3）フ ロッピーディスク (FD)へのデータの収納, で ある。これらは機能ごとにアセンブラーでサブ ルーチンが作成され，それらをベーシックの主 プログラムで組合わせて, キーボードからのワ ンタッチ入力によって必要な操作が行えるよう にプログラムが作成されている。サンヨーM B C225（S-ベーシック）を用いる場合の操作の フローチャートをFig. 8 に示した。 NEC 9801 F 2 を使用する場合には, 基本的機能は等しい が, さらに機能の向上が図られ, 予じめ設定し たメニューに沿った繰返し測定, 数秒毎のAスコープ (相関演算の結果) の表示, 距離自乗 補正, 平滑化処理等を行うことができる。

\section{5 . 測定例}

Fig. 2 に示すように装置が理想通りに働けば,

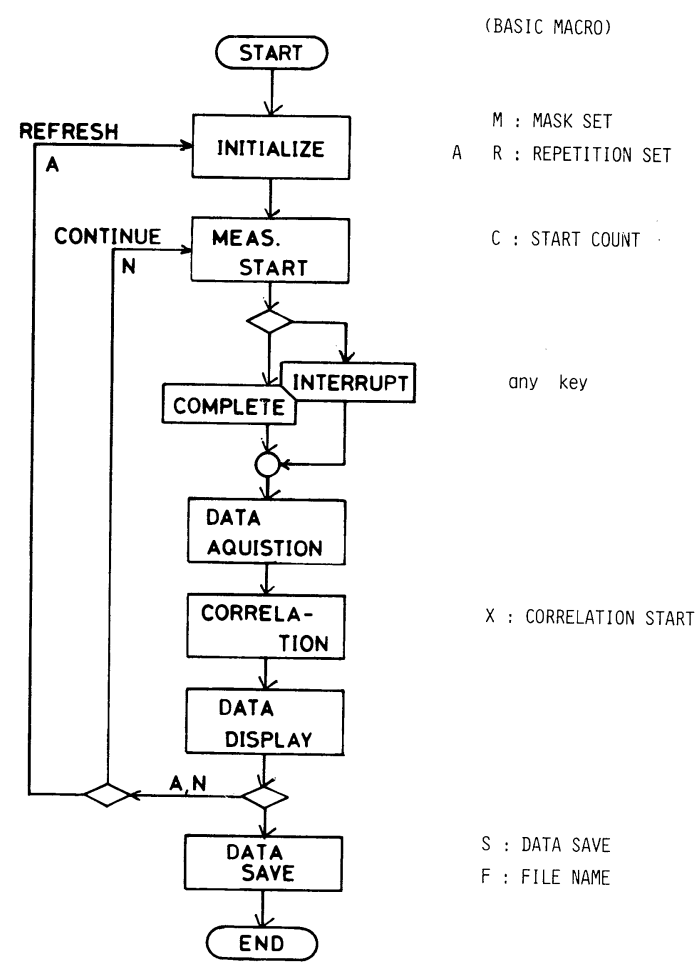

Fig. 8 Flow diagram of a data aquisition and analysing programs.

夜間の測定では視程 $5 \mathrm{~km}$ に相当するエアロゾル に対して，600 mの距離に対し，積算時間10秒で $\mathrm{S} / \mathrm{N}=10$ (空間分解能 $9 \mathrm{~m}$ ) が得られる筈であ る。しかし現状では変調されたレーザー光波形 の歪みや受信回路へ回り込む雑音のために計算 值通りの $\mathrm{S} / \mathrm{N}$ は得られていない。本論文では検 出器として A P D使用時の紙, 雪, 煙等からの 散乱信号, P M Tに変えてからのエアロゾルや 雲の測定, 視程の観測, 昼間時における樹木か らの散乱信号について報告し，次節で $\mathrm{S} / \mathrm{N}$ 低下 の問題点を検討する。

\subsection{A P D による検出例}

装置を小型化し，操作を簡易化するには，装置 全体を固体素子化(ソリッド化)することが望ま しい。装置全体をソリッド化する観点から，原 仕様では検出器にAPDを採用した。APDでは 動作時の雑音はアバランシェ作用により増倍率 $M_{\mathrm{D}}$ とともに $M_{\mathrm{D}}{ }^{1+x}$ 倍（シリコンを素材とする $\mathrm{A}$ 
$\mathrm{PDでは} x=0.25 ）$ に増大するので，通常 $M_{\mathrm{D}}$ $=100$ ３00程度が限界となる。したがって A P $\mathrm{D}$ を検出器とする場合には後段の増幅器雑音を 無視できず，低雑音・高利得の増倍器を必要と する。この事情も考慮したうえでA P D を検出 器として採用したが，小信号時における A D C の動作不良のためにエアロゾル等の低濃度な散 乱体を測定するに十分な性能が得られなかった。 そのため検出器を $\mathrm{PMT}$ T変更した訳であるが, A P Dには 1) 入出力関係のダイナミックレン ジが広い，2）過大入力信号に対して素子が丈 夫である，3）検出感度が長波長側へ延びてい る，4）素子自体（冷却器を必要とする場合は別 である）は小型である，等の長所がある。した がって可能なかぎり A P D を使用することが望 しい事情は依然として重要である。

A P D を検出器としても，高濃度な散乱体の 空間分布や建造物までの距離の測定は可能であ

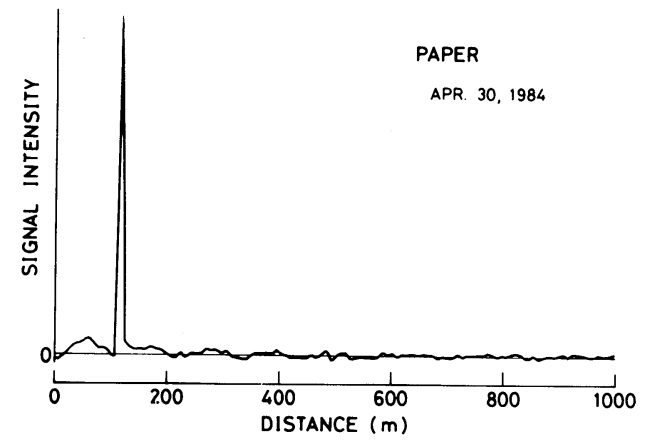

Fig. 9 Lidar echo signal from a paper envelope with an APD detector.

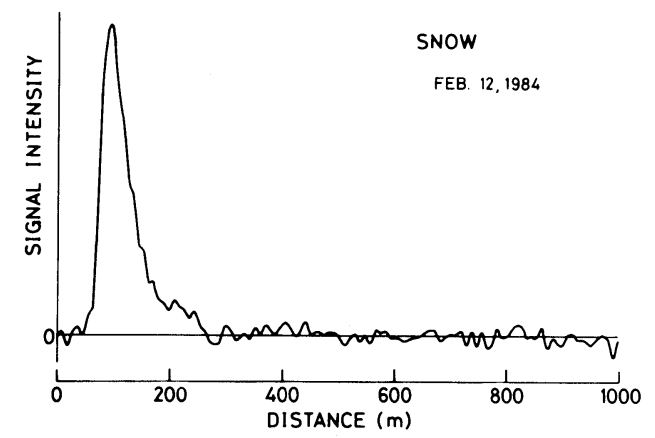

Fig. 10 Lidar echo signal from falling snow with an APD detector.
る。Fig. 9〜10に紙，雪からのエコー信号を示 す。Fig. 9は120m先にたてたポールに貼りつけ た茶封筒からのエコー信号である。レーザービ 一ムの拡がりは $150 \mathrm{~m}$ 先で $2 \sim 3 \mathrm{~cm}$ であるので, 茶封筒よりも小さいスポットとなる。Fig.10は 降雪時におけるエコー信号である。100mまでの部 分はレーザービームが望遠鏡視野に含まれる割 合 $Y(R)$ （クロスオーバー関数）を示している。 Fig.10の例では, $60 \mathrm{~m}$ からレーザービームは望 遠鏡視野と重なり始め, $100 \mathrm{~m}$ でビーム全体が視 野に含まれることを示している。100mでエコー 信号はピークに達した後, 雪によるレーザー光 透過率の減衰によって $270 \mathrm{~m}$ の地点で雑音レベル 以下となる。そのほか発煙筒からの煙も A P D によって測定されているが, ここでは省略する。

\section{2 エアロゾル，雲}

大気境界層構造（逆転層高度，混合層の厚さ など）を測定するにはエアロゾル濃度の空間分
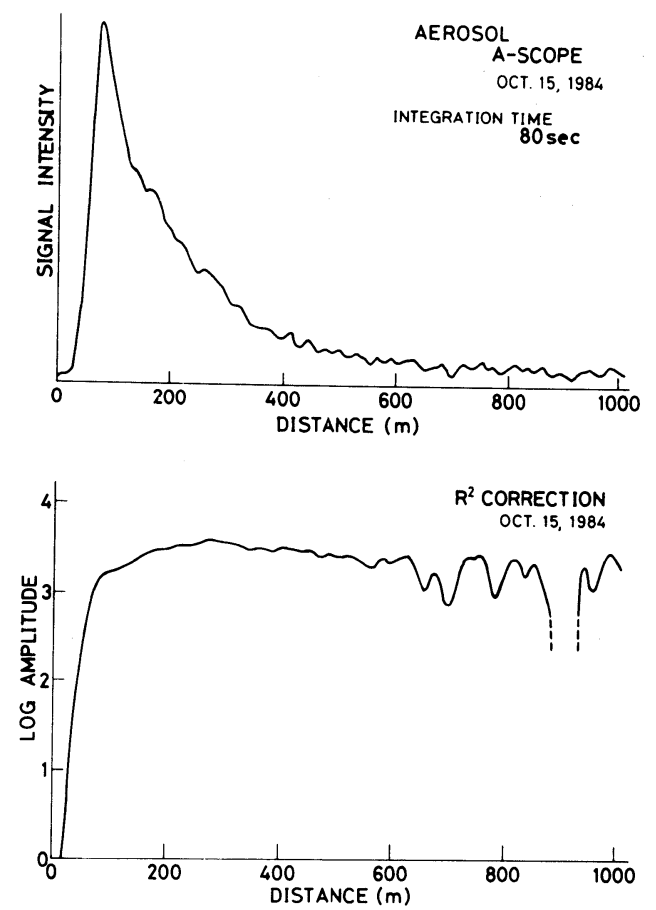

Fig. 11 Lidar echo from boundary layer aerosol with a PMT detector (elevation angle 5 deg.) (a) A-scope, (b) range squqre corrected. 
布が測定できることが必要である。A P D を検 出器とした場合, 増幅器利得がA D Cへの入力 信号レベルを得るのに十分でないので，検出器 をP M T に変更した。その結果得られた夜間工 アロゾル測定の 1 例をFig. 11に示す。測定時の ライダー高位角は約 $5^{\circ}$ で測定の積算時間は 80 秒 である。Fig. 11(a)にはA-スコープを，Fig. 11 (b)には距離自乗補正後，対数表示した結果を示 してある。Fig. 11(b)で見られる距離 $650 \mathrm{~m}$ 拊近 におけるへこみは逆転層高度に対応しているよ うに思われる。(それ以遠ではエアロゾル濃度が 低く，信号レベルが小さいため，受信回路に回 り込む雑音によって十分な $\mathrm{S} / \mathrm{N}$ が得られていな い。)

Fig. 12にはPMTを用いて行った雲の測定の 1 例を示す。測定の積算時間は約30秒で, 高位 角は $30^{\circ}$ であった。Fig. 12 では $5 \mathrm{~km}$ 遠方 (高度 2.5 $\mathrm{km})$ の雲が受光されている。薄い雲に対しては 層状構造も観測される。

\section{3 視 程}

視程は大気污染の 1 つの目安であるばかりで なく，航空機，船舶等の航行上も重要な情報で ある。特に悪視程の場合には大きな航空機事故 にもつながるので，空港における地上レベルの 視程は透過率計 (transmissometer) によって 常時監視されている。それに対し，着陸時にパ イロットが必要とする視程は，操従席から滑走 路を見るものであり，斜め視程と呼ばれている。 着陸時の進入角度は約 $2^{\circ}$ であるが, 着陸地点よ

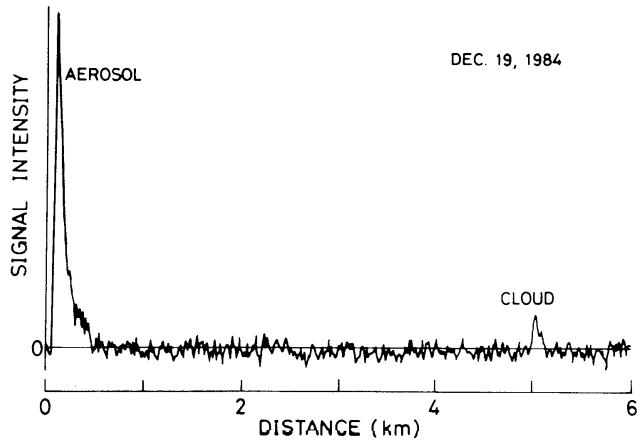

Fig. 12 Lidar echo from a cloud at $5 \mathrm{~km}$ disdistance.
りも近くを見下ろすので，視線方向としては 2 〜 $9^{\circ}$ 範囲となる。斜め視程の場合には地上に ベースラインをとることができないので, ライ

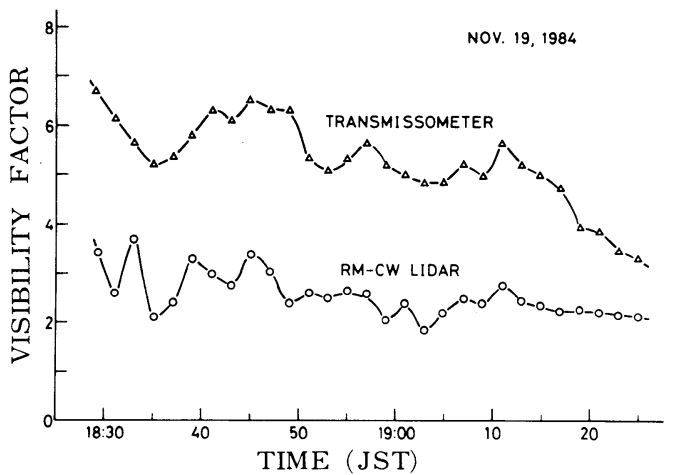

Fig. 13 Visibility measurement by transmissometer and $\mathrm{RM}-\mathrm{CW}$ lidar. In a case of lidar, sope method is used for der. ivation. (Nov.19, 1984)

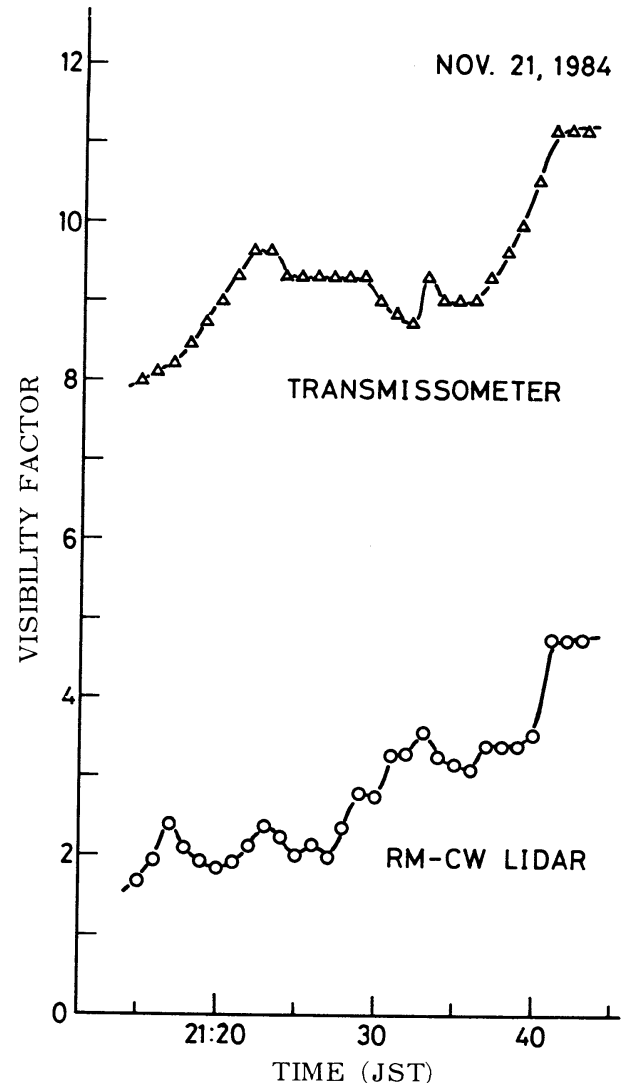

Fig. 14 The same as in Fig. 13 except the observation date (Nov.21, 1984) 
ダーのように送受光を同一地点で行う単一局方 式が優れている。高位角を小さくとった場合, 地上附近の接地境界層中のエアロゾル濃度は一 様であると仮定し，スロープ法を適用して視程 の導出を試みた。距離自乗補正し, 対数表示を 行ったデータ上で適当な直線区間を選定し，そ の区間での傾きを最小自乗法により求めた。そ の結果をFig. 13, Fig. 14に示す。測定に際し ては, 空港で使用しているものと同種の透過率 計 (ベースライン $152.4 \mathrm{~m}$, 地上 $3 \mathrm{~m}$ ) を作動させ, それより得られた視程をFig. 13，14中に同時に 示してある。ライダーの測定は高位角 $5^{\circ} に$ 設定 し, 一定間隔毎に自動繰返し測定を行った。 Fig. 13の例では 2 分間隔で測定し, 測定の積算 時間は40秒である。Fig. 14の例はFig. 13 より 視程が良い場合の測定であるが，1 分間隔で20 秒間積算して測定した。いずれの場合も，測定 值を視程に変換する換算方式が未確定のため, 視程の絶対値としての比較はまだ結論づけられ ていないが, デー夕から推定する限り，かなり 高い相関性をもっていることが示された。すな わち Fig. 13，14に示されるように視程の時間 変化の傾向は良く一致しており，さらに水平の パスと斜め方向のパスの差異に基くと考えられ る部分差も見出され, 斜め視程の計測装置とし ての実用化に大きく前進したものと言えよう。

\section{4 昼間測定}

昼間時に測定を行うためには，背景光の影響 を極力除去する必要がある。そのためには1） 受光視野角を極力，小さく設定する。2）レー ザー波長を狭帯域光学フィルターの中心波長に 固定し，背景光を制限することが有効である。 1 ）に関してはLD光源は $0.1 \mathrm{mrad}$ 以下のビー ム拡がりにできるので，長焦点の受光望遠鏡を 用いて受光視野角を小さく（ビーム拡がりの 2 倍程度に）することが望しい。残念ながら，使 用した装置では有効焦点距離は $40 \mathrm{~cm}$ であったの で，視野角を $2 \mathrm{mrad}$ 以下にすることは難しか った。2）に関してはL D の動作温度をペルテ イエ素子によって調節し，LD発振波長を光学

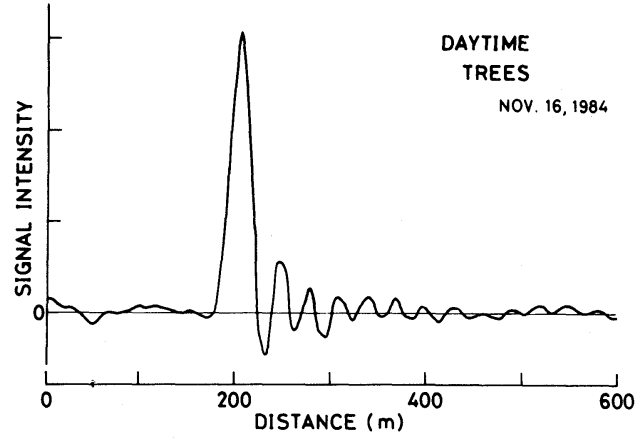

Fig. 15 Lidar measurement in the daytime. Echo is from trees. PMT voltage is lowered by $200 \mathrm{~V}$ to get rid of PMT saturation.

フィルターの中心波長附近に設定して昼間時の 測定を試みた。エアロゾルの測定にはさらに装 置性能の向上を図る必要があるが，建造物に対 してはエコー信号を得ることができた。 $200 \mathrm{~m}$ 先の樹木から得られた散乱信号の 1 例をFig. 15 に示す。(反射信号後方の波状の波形は強い信号 に対する増幅器の非線形応答による。)

\section{6.おわりに}

現在, 半導体レーザー (LD) は光通信, コン パクトディスク, レーザープリンターなどの分 野で急速に普及しており, さらに広い応用分野 が期待されている。その応用分野の一つとして, 本報告では L D を光源とする擬似ランダム変調 $\mathrm{CW}$ ( RM-CW)ライダーの試作とその動作例に ついて報告した。L D を光源とするライダーと しては, $10 \mathrm{~W}$ 以のパルス動作で雲底高度計や $150 \mathrm{~m}$ 以下の距離計に応用されており, 斜め視程 計への試みも報告されているが, 今後最も有望 な $\mathrm{cw}$ 動作のLDを用いた報告はない。本報告で は低出力の $\mathrm{cw}$ 動作でも高感度を得るために擬似 ランダム変調方式を採用した。全固体化を考え た当初の設計では検出器としてAPDを採用し, 建造物や雨・雪・煙からのエコーを得た。さら に低濃度のエアロゾル空間分布を測定するため に検出器を P M Tに変えて, 夜間, 数 $100 \mathrm{~m}$ ま゙ エアロゾルを観測することができた。

装置は小型・可搬型の観点から製作された。 
試作機であるのでL D を採用した効果は十分に 発輝されていないが，ライダーヘッド（送受光 部), 信号処理部, 制御部 (パソコン) の各部 に分けて，1 人でライトバン等に搭載し, 運搬 ・操作することが可能である。

試作した装置は，小信号入力に対する A D C の動作不良, 光学系の収差, 変調波形の歪み, 受信回路への電気雑音の混入などを改良するこ とによってさらに数十倍の S/Nの改善が期待で きる。本報告では， L D を光源とした $\mathrm{RM}-\mathrm{CW}$ ライダーの基礎特性を報告したが，問題点を解 決し，さらに高出力の L D を使用することによ り, 初期の目標性能を達成し, 小型軽量で低価 格なライダー装置が実現するのも遠くないと確 信する。

最後に, 本レーザーレーダーの試作・実験に 御協力戴いた明星電気(侏)守谷工場技術部の諸氏, および CW半導体レーザーに関していろいろと 御教示下さったシャープ中央研究所土方俊樹部 長，矢野盛規課長に感謝致します。

\section{参 考 文 献}

1) E. D. Hinkley ed. : Laser Monitoring of the Atmosphere (Topics in Applied Physics Vol. 14) (SpringerVerlag, Berlin, 1976) 380p.
2) H. Shimizu et al. : Appl. Opt. 24 (1985) 617.

3) N. Takeuchi et al.: Opt. and Laser Remote Sensing, (ed. D. K. Klllinger and A. Mooradian), (Springer Ser, in Optical Sciences, Vol. 39, Springer-Verlag, Berlin), 1983. pp. 288-298.

4) N. Takeuchi, N. Sugimoto, H. Baba and K. Sakurai : Appl. Opt. 22 (1983) 1382.

5) 竹内延夫 - 杉本伸夫, 桜井捷海, 馬場浩司, 上野敏 行：レーザー研究, 11 (1983) 763.

6) R. A. Ferguson: Feasibility of a CW lidar technique for measurement of plume opacity, SRI Report for EPA, EPA-650/2-73-037 (PB-231 992) (1973) 90p.

7) T. Kobayashi et al. : FM-CW laser radar for differential absorption measurements of atmospheric gases using topographic targets, 12th Int. Laser Radar Conf., Aix en Provence, France 19 (1984) 417-418.

8) Spectra Diode Labs: $100 \mathrm{~mW}$ cw GaAlAs Laser Diode Model, SDL-2410-D1.

9) M/A Com Laser Diode: Single heterojunction GaAs laser diode arrays for pulsed operation, LD-410.

10) D. R. Scifres et al: Appl. Phys. Lett. 41 (1982) 1121.

11) Y. Suematsu et al. : IEEE J. Lightwave Technol. LT1 (1983) 161.

12) Ch. Werner and H. Herrmann: Application to an eye-safe-laser slant visual range measuring device at Munich-airport, 12th Int. Laser Radar Conf., Aix en Provence, France B5 (1984) 47.

13) 明星電気(侏)雲底高度計 TXK- 3 型

14) D. R. Scifres et al. : Appl. Phys. Lett. 42 (1983) 645.

15) 佐藤擬似ランダム系列, 磯部編, 相関関数及びスペ クトル, III-2, 東大出版会 (1968).

16) R. H. Kingston: Detection of optical and infrared radiation (Springer Series in Optical Sciences vol. 10), (Springer-Verlag, Berlin, 1979) pp. 47-50. 